УДК 664:67

DOI https://doi.org/10.32838/TNU-2663-5941/2020.3-2/13

Токар А.Ю.

Уманський національний університет садівництва

Харченко 3.М.

Уманський національний університет садівництва

Матенчук Л.Ю.

Уманський національний університет садівництва

\title{
Войщехівський B.I.
}

Національний університет біоресурсів і природокористування України

\section{ОВОЧЕВО-ФРУКТОВІ ПЮРЕ ФУНКЦІОНАЛЬНОГО ПРИЗНАЧЕННЯ ЗА ЗАСТОСУВАННЯ ІННОВАЦИЙНОГО ОБЛАДНАННЯ}

У статті наведено результати дослідження з розроблення овочево-фруктових пюре з плодів гарбуза, моркви, аличі та волоських горіхів. Нові види пюре: гарбузово-аличеве з горіхами, морквяно-аличеве з горіхами та гарбузово-морквяно-аличеве з горіхами перевершують пюре з однойменних овочів за вмістом компонентів хімічного складу. Досліджено два варіанти рецептур, щзо відрізнялися між собою за кількістю доданого аличевого пюре. Зважаючи на органолептичну очінку якості, надано перевагу рецептурі, за якою додається 70\% овочевого пюре, 20\% - аличевого, по 5\% - горіхів і иукру. Зокрема купажовані пюре, виготовлені за такою рецептурою, містять сухих розчинних речовин $18,8 \ldots 19,4 \%$, иукрів - близько 12\%; титрована кислотність - 0,7\%, активна кислотність - 3,7 од. pH, щяо забезпечує вищу мікробіологічну стабільність. Нові види пюре також містять природні жири, багаті на ненасичені жирні кислоти й пектини. Купажовані пюре мають приємну кислинку, обумовлену вмістом натуральних органічних кислот, й отримали органолептичну оцінку якості 4,85...4,90 бала. Вміст аскорбінової кислоти в пюре гарбузово-аличевому з горіхами - 15,3 мг у 100 2, $\beta$-каротину -14,1 мг у 100 г, у пюре морквяно-аличевому з горіхами та в пюре гарбузово-морквяно-аличевому з горіхами відповідно 6,8, 15,4 й 11,6, 14,9. Такі пюре за вмістом $\beta$-каротину є функиіональними продуктами та можуть бути використані як збагачувачі иим інгредієнтом для приготування різних харчових продуктів. За вмістом аскорбінової кислоти пюре, до рецептури яких входить гарбуз, можна вважати функиіональними продуктами за циим інгредієнтом. Розроблені рецептури купажованих пюре забезпечують приготування продуктів з підвищеною біологічною иінністю, покращеними органолептичними ŭ функиіональними властивостями. Результати дослідження можна запропонувати для використання в молочній, хлібопекарній, консервній промисловості та в закладах ресторанного господарства.

Ключові слова: плоди гарбуза, моркви, аличі, волоського горіха, купажовані пюре, аскорбінова кислота, $\beta$-каротин, функціональні продукти, збагачувачі.

Постановка проблеми. Значна кількість (до $20-50 \%$ ) овочевої та фруктової сировини втрачається на шляху від поля до споживача. Тому своєчасне переробляння дешевої рослинної сировини на конкурентоспроможні продукти за збереження природних біологічно активних речовин має актуальне значення у вирішенні Продовольчої програми в Україні. Спроби вирішення проблеми використання рослинної сировини у виробництві молочних, кулінарних, борошняних кондитерських виробів, напоїв і страв 3 метою підвищення біологічної цінності чи забезпечення їхніх функціональних властивостей простежуються в наукових працях В.С. Баранова, М.I. Пересічного,
С.М. Пересічної, 3.В. Василенко, М.Ф. Кравченко, М.М. Калакури, І.В. Сирохмана, П.П. Пивоварова, Ф.В. Перцевого, В.А. Колтунова, Н.В. Притульської, Л.П. Малюк, Г.В. Дейниченко, М.І. Філя та інших українських і зарубіжних учених.

Аналіз останніх досліджень i публікацій. Здоров'я сучасної людини залежить від рівня й структури харчування, порушення яких виявляє непоправну, на декілька порядків вищу шкоду в порівнянні з екологічною забрудненістю. Структура харчування сучасної людини має серйозні порушення, зокрема надлишкове вживання тваринних жирів і дефіцит поліненасичених жирних кислот, повноцінних тваринних білків, мінеральних 
елементів, вітамінів (C, Р, групи В, фолієвої кислоти, ретинолу, $\beta$-каротину). Споживання зазначених інгредієнтів нормується ВООЗ, щоденне їх надходження до організму людини є необхідним. Для покращення структури харчування в Україні актуальним $є$ створення продуктів на основі овочів і фруктів з підвищеним вмістом харчових волокон, пектинів та інших нутрієнтів [1-3].

Аскорбінова кислота (вітамін С) - найбільш поширений у рослинному світі вітамін. В організмі людини діє як антиоксидант, бере участь у процесах тканинного дихання, у забезпеченні біосинтезу нуклеїнових кислот, білків та інших сполук, поліпшує засвоюваність заліза, бере участь у процесах кровотворення. Джерелом аскорбінової кислоти є овочі та фрукти. Фізіологічна потреба дорослої людини в аскорбіновій кислоті становить 90 мг на добу [4, с. 34-35]. За недостачі вітаміну А уражуються очі, шкіра й слизові оболонки органів дихання й шлунково-кишкового тракту стають сухими, спостерігається ороговіння епітелію, дерматити. Нестача вітаміну А є фактором ризику інфекційних захворювань і виникнення злоякісних новоутворень. Вітамінна активність $\beta$-каротину вдвічі нижча, він краще засвоюється в кишечнику 3 відвареної моркви, ніж із сирої. Фізіологічна потреба у $\beta$-каротині складає 5 мг на добу, але не більше 10 мг. Морква й гарбуз досить багаті $\beta$-каротином, вміст якого відповідно 9,0 та 1,5 мг на 100 г [4, с. 26-28]. За даними Т. Кравець [5] алича містить вітаміну С 3-18 мг/100 г, $\beta$-каротину - до 2,16 мг/100 г, плоди багаті на цукри (до $11 \%$ ) й органічні кислоти $(1,0-6,9 \%)$ [6]. Овочі та фрукти $є$ джерелом пектинових речовин, що позитивно впливають на різні процеси в організмі людини: сприяють зниженню вмісту ліпідів, стимулюють життедіяльність кишкової мікрофлори, є синергістами вітамінів (підсилюють їхню активність). Пектинові речовини ефективні в профілактиці атеросклерозу, вони нормалізують метаболізм холестерину. Добова потреба пектину - 2 г на добу [4, с. 96]. Морква, гарбуз й алича традиційно багатогранно застосовуються у виготовленні різних страв. Зокрема, з них готують салати, пюре, супи-пюре, смузі, солодкі соуси, напої, напівфабрикати [7, с. 233, 234, 247, 248; 8$, c. $38,72,98]$.

Досить часто в рецептуру продуктів харчування з рослинної сировини вчені вводять ядра волоського горіха різного ступеня стиглості [9]. Дані про хімічний склад ядра горіхів досліджено B.С. Степановою $[10$, с. 105,106$]$. Масова частка сухих речовин у горіхах складається $363 \%$ жирів і до 15,2\% білків. Дослідження амінокислотного складу й підрахований амінокислотний скор свідчать, що білок ядра волоського горіха $\epsilon$ повноцінним, а лімітуючою амінокислотою є лізин на рівні $51 \%$. Ліпідна частина більш ніж на $80 \%$ складається 3 ненасичених жирних кислот, зокрема $53 \%$ - лінолева жирна кислота, а 12,7\% - ліноленова жирна кислота; співвідношення жирних кислот $\omega-3$ та $\omega-6$ - на рівні 1:4. Ядра горіха мають високий вміст токоферолів (вітамін Е) з антиоксидантними властивостями та значний вміст калію, фосфору й магнію.

На сьогодні вже $є$ розробки харчових продуктів нового покоління з використанням гарбузів чи моркви, різних фруктів і напівфабрикатів з них.

Зокрема О.А. Іваніщева [11] на основі наявних страв розробила страви «Каша гарбузова в'язка 3 пшоном та медом», «Суп-пюре з гарбуза та імбиру на кокосовому молоці», «Крем-суп з гарбуза з шротом насіння вівса». В.А. Гніцевич, Р.П. Никифоров, Н.А.Федотова, Н.В. Кравченко [12, с. 24, 25] зазначають, що пектинові речовини використовуються в технологіях структурованої продукції як харчова добавка драглеутворювальної дії. Тому вирішення проблеми забезпечення харчової галузі дешевими драглеутворювачами полягає у використанні різних видів овочевих і фруктових пюре. Вчені з Харкова розробили рецептури й технології нового покоління бісквітів і булочок, вітамінізованих натуральними каротиноїдними дрібнодисперсними добавками (замороженими або термообробленими) з моркви або гарбуза у вигляді пюре, отриманого без застосування синтетичних компонентів для оздоровчого харчування школярів і різних верств населення з метою імунопрофілактики [13]. На основі яблук (30\%) з додаванням гарбуза, обліпихи й аронії чорної (по 20\%), буряка (10\%) розширено асортимент плодоовочевих паст, які можуть бути використані як згущувач і наповнювач, вітамінна добавка в таких галузях, як кондитерська, консервна, молочна, хлібопекарська, а також у закладах ресторанного господарства [14]. У процесі вдосконалення технології виробів із дріжджового тіста 3 використанням соку, пюре й вичавків із гарбуза та проведення мікробіологічних досліджень установлено, що готові вироби характеризуються високою якістю, мікробіологічною стабільністю й рекомендуються до впровадження в заклади ресторанного господарства [15].

Водночас виготовлення овочево-фруктових пюре 3 вдалим поєднанням рослинної сировини ще недостатне. 
Постановка завдання. Метою статті є дослідження дешевої місцевої сировини й розроблення на ii основі овочево-фруктових пюре підвищеної біологічної цінності. Було поставлено такі завдання:

- дослідити вміст компонентів хімічного складу плодів гарбуза, моркви, аличі та волоських горіхів, вирощених в умовах лісостепу України;

- приготувати пюре, визначити рецептури, що забезпечують найкращі органолептичні показники;

- дослідити зразки пюре й визначити вміст біологічно активних речовин.

Виклад основного матеріалу дослідження. Для дослідження брали плоди гарбуза сорту Новинка, моркви сорту Вітамінна-6, аличі сорту Обільна, горіхи сорту Топорівський. Плоди гарбуза й моркви мили, очищали, інспектували, обполіскували, подрібнювали на шматочки розміром 5-10 мм, припускали за температури $98 \pm 2^{\circ} \mathrm{C}$, 15-20 хв 3 додаванням 10-15\% прокип'яченої води. Протирали через сито з нержавіючої сталі 3 діаметром отворів $0,75-0,80$ мм.

Плоди аличі використовували цілі, спілі, здорові, не уражені хворобами й без ознак псування. Плоди сортували, ретельно мили питною водою, відривали плодоніжки та інспектували. Ножем розрізали плоди, витягали кісточки. Після видалення кісточок плоди подрібнювали за допомогою м'ясорубки й розварювали 10 хвилин за температури $98 \pm 2{ }^{\circ} \mathrm{C}$. Розварену масу протирали вручну через сито 3 нержавіючої сталі $з$ діаметром отворів 0,75-0,80 мм. Підготовлене пюре розливали в лотки, заморожували й зберігали до використання за температури $-18{ }^{\circ} \mathrm{C}$.

Ядра горіха сортували за якістю й подрібнювали до порошкоподібного стану.

Підготовлені компоненти змішували за рецептурами: овочеве пюре з гарбуза, моркви чи гарбуза й моркви у співвідношенні 1:1 - 700 г, пюре 3 аличі - 200 г, цукор білий і подрібнене ядро горіха по 50 г (І варіант); овочеве пюре 3 гарбуза, моркви чи гарбуза й моркви у співвідношенні 1:1 - 750 г, пюре 3 аличі - 150 г, цукор білий і подрібнене ядро горіха по 50 г (II варіант). Разом 1000 г. Для забезпечення гомогенності застосовували сучасне інноваційне обладнання - блендер RESTO LINE EASYLINE BL020B 3 швидкістю обертання 28000 об/хв італійського виробництва.

Після змішування пюре проварювали за слабкого кипіння та перемішування протягом 15 хвилин. За контроль брали відповідні однойменні овочеві пюре.

Під час дослідження показників якості сировини й готових пюре застосовували стандартні методи дослідження [16-21].

За вмістом сухих розчинних речовин (далі СРР) переважають горіх й алича. Масова частка сухих розчинних речовин в аличі перевищує показник на $2,2 \%$, а в гарбузах на $1 \%$ (див. табл. 1.)

Вміст цукрів у плодах аличі був вищим у 1,6 раза порівняно з їхнім вмістом у гарбузах і моркві. Вміст цукрів у складі СРР у плодах аличі найвищий $(67,8 \%)$, що значно більше в порівнянні 3 морквою $(48,6 \%)$ і гарбузом $(45,4 \%)$.

Смак плодів залежить від наявності в них органічних кислот. За вмістом цього показника алича $\epsilon$ беззаперечним лідером і посідає перше місце 3-поміж досліджуваної сировини (табл. 1). Титрована кислотність (далі-ТК) плодів аличі в 13,5 раза більша порівняно 3 плодами моркви та ядром горіха і в 9,0 разів більша, ніж у плодів гарбуза.

На відміну від іншої рослинної сировини ядра горіха містили жир в кількості 58,6\%.

Аскорбінова кислота (вітамін С) - один з найважливіших вітамінів, фізіологічне значення його для організму людини різноманітне [4, с. 34]. Плоди гарбуза вирізнялися найвищим вмістом аскорбінової кислоти (далі - АК) і переважали

Таблиця 1

Вміст компонентів хімічного складу в сировині

\begin{tabular}{|c|c|c|c|c|c|c|c|}
\hline \multirow[b]{2}{*}{ Сировина } & \multicolumn{4}{|c|}{ Масова частка, \% } & \multicolumn{2}{|c|}{ Вміст, мг/100 Г } & \multirow[b]{2}{*}{$\begin{array}{c}\text { Цукрово- } \\
\text { кислотний } \\
\text { індекс }\end{array}$} \\
\hline & $\begin{array}{c}\text { сухих } \\
\text { розчинних } \\
\text { речовин }\end{array}$ & цукрів & $\begin{array}{c}\text { титрованої } \\
\text { кислотності } \\
\text { (в перерахунку на } \\
\text { яблучну кислоту) }\end{array}$ & жирів & $\begin{array}{l}\text { аскорбінової } \\
\text { кислоти }\end{array}$ & $\beta$-каротину & \\
\hline Алича & 16,4 & 11,1 & 2,7 & & 17,0 & 1,7 & 4,1 \\
\hline Морква & 14,2 & 6,9 & 0,2 & & 8,2 & 24,5 & 34,5 \\
\hline Гарбуз & 15,4 & 7,0 & 0,3 & & 23,7 & 22,9 & 23,3 \\
\hline Горіx & 16,8 & 7,1 & 0,2 & 58,6 & 6,2 & 0,1 & 35,5 \\
\hline $\mathrm{HIP}_{05}$ & 0,2 & 0,02 & 0,02 & & 0,1 & 0,1 & 0,2 \\
\hline
\end{tabular}


плоди аличі в 1,4 раза, плоди гарбуза - у 2,9 раза, а ядра горіхів - у 3,8 раза.

Моркву й гарбуз цінять за антиоксидантні властивості, які пов'язують із вмістом таких компонентів, як $\beta$-каротин і АК [22, с. 34]. $\beta$-каротин завжди високо цінували, він в організмі людини здатний перетворюватися на вітамін А. Найвищий його вміст у плодах моркви, на 1,6 мг/100 г менше в плодах гарбуза, у 14,2 раза менше в плодах аличі, у 245 разів менше визначено в горіхах.

Аналіз цукрово-кислотного індексу (далі ЦКІ) виявив, що показник найбільш сприятливий у плодів гарбуза, у плодів моркви й горіхів - високий, а у плодів аличі - занадто низький. Тому, для покращення органолептичної оцінки купажування дослідженої сировини доцільне.

Оцінюючи якість плодів гарбуза сорту Новинка за вмістом АК і $\beta$-каротину, можна сказати, що вони вирізнялися високим вмістом цих нутрієнтів. Аналогічне можна сказати про плоди моркви сорту Вітамінна-6 за вмістом $\beta$-каротину.

Під час припускання, протирання овочів і припускання, протирання аличі та зберігання аличевого пюре спостерігалася зміна вмісту компонентів хімічного складу (табл. 2).

Зміну вмісту СРР, цукрів можна пояснити частковим руйнуванням чи розведенням водою під час припускання (табл. 1 і 2). Зниження вмісту АК під час виготовлення та зберігання в замороженому вигляді пюре з аличі - 7,6 \%, виготовлення пюре 3 моркви - 29,3\%, з гарбуза - 13,5\%. Відповідно відсоток зниження вмісту $\beta$-каротину в пюре порівняно з його вмістом у плодах $-11,8 ; 4,9 ; 6,6$.

Додавання цукру в купажовані пюре обумовило підвищення вмісту СРР і цукрів порівняно 3 однойменними, взятими за контроль (табл. 3).

Вміст компонентів хімічного складу в пюре-напівфабрикатах

\begin{tabular}{|c|c|c|c|c|c|c|}
\hline \multirow[b]{2}{*}{ Пюре: } & \multicolumn{3}{|c|}{ Масова частка, \% } & \multicolumn{2}{|c|}{ Вміст мг/100 г } & \multirow[b]{2}{*}{$\begin{array}{c}\text { Цукрово- } \\
\text { кислотний } \\
\text { індекс }\end{array}$} \\
\hline & $\begin{array}{c}\text { сухих } \\
\text { розчинних } \\
\text { речовин }\end{array}$ & цукрів & $\begin{array}{c}\text { титрованої } \\
\text { кислотності } \\
\text { (в перерахунку на } \\
\text { яблучну кислоту) } \\
\end{array}$ & $\begin{array}{c}\text { аскорбї- } \\
\text { нової } \\
\text { кислоти }\end{array}$ & $\beta$-каротину & \\
\hline Аличеве & 16,2 & 10,9 & 2,7 & 15,7 & 1,5 & 4.2 \\
\hline Морквяне & 13,9 & 6,6 & 0,2 & 5,8 & 23,3 & 33 \\
\hline Гарбузове & 15,0 & 6,7 & 0,3 & 20,5 & 21,4 & 22,3 \\
\hline $\mathrm{HIP}_{05}$ & 0,2 & 0,2 & 0,03 & 0,3 & 0,6 & 0,02 \\
\hline
\end{tabular}

Таблиця 3

Вміст компонентів хімічного складу в готових пюре

\begin{tabular}{|c|c|c|c|c|c|c|}
\hline \multirow{2}{*}{ Назва пюре } & \multicolumn{3}{|c|}{ Масова частка, \% } & \multicolumn{2}{c|}{ Інші показники } \\
\cline { 2 - 6 } & СРР & цукрів & ТК* & жиру & $\begin{array}{c}\text { активна } \\
\text { кислотність, од. } \mathbf{~} \mathbf{H}\end{array}$ & ЦКІ \\
\hline $\begin{array}{c}\text { Пюре 3 гарбуза } \\
\text { (контроль) }\end{array}$ & 15,0 & 6,7 & 0,3 & - & 4,6 & 22,3 \\
\hline $\begin{array}{c}\text { Пюре гарбузово-аличеве 3 горіхами } \\
\text { (І варіант) }\end{array}$ & 19,4 & 12,3 & 0,7 & 2,9 & 3,6 & 17,6 \\
\hline $\begin{array}{c}\text { Пюре гарбузово-аличеве 3 горіхами } \\
\text { (ІІ варіант) }\end{array}$ & 19,5 & 12,0 & 0,6 & 2,9 & 3,9 & 20,0 \\
\hline $\begin{array}{c}\text { Пюре з моркви } \\
\text { (контроль) }\end{array}$ & 13,9 & 6,6 & 0,2 & - & 4,7 & 33 \\
\hline $\begin{array}{c}\text { Пюре морквяно-аличеве з горіхами } \\
\text { (І варіант) }\end{array}$ & 18,8 & 12,2 & 0,7 & 2,9 & 3,7 & 17,4 \\
\hline $\begin{array}{c}\text { Пюре морквяно-аличеве з горіхами } \\
\text { (ІІ варіант) }\end{array}$ & 17,9 & 11,9 & 0,6 & 2,9 & 3,9 & 19,8 \\
\hline $\begin{array}{c}\text { Пюре морквяно-гарбузове } \\
\text { (контроль) }\end{array}$ & 14,5 & 6,7 & 0,3 & & 4,6 & 22,3 \\
\hline $\begin{array}{c}\text { Пюре морквяно-гарбузово-аличеве } \\
\text { з горіхами (І варіант) }\end{array}$ & 19,2 & 12,0 & 0,7 & 2,9 & 3,7 & 17,1 \\
\hline $\begin{array}{c}\text { Пюре морквяно-гарбузово-аличеве } \\
\text { з горіхами (ІІ варіант) }\end{array}$ & 19,0 & 12,0 & 0,6 & 2,9 & 3,9 & 20,0 \\
\hline НІР 05 & 0,3 & 0,6 & 0,03 & & 0,03 & 0,6 \\
\hline
\end{tabular}

Примітка: * - у перерахунку на яблучну кислоту 
Масова частка титрованої кислотності підвищилась у пюре, виготовлених за I варіантом (3 додаванням 200 г аличевого пюре) до $0,7 \%$ та до $0,6 \%$ за II варіантом (з додаванням 150 г аличевого пюре).

Таке підвищення титрованої кислотності в I варіанті обумовило зниження активної кислотності відповідно до 3,6 од. $\mathrm{pH}$ у пюре гарбузовоаличевому, до 3,7 од. $\mathrm{pH}$ - у пюре морквяно-аличевому й морквяно-гарбузово-аличевому та в усіх купажованих пюре за II варіантом - до 3,9 од. $\mathrm{pH}$. І це дуже важливо, бо купажовані пюре за рН $<3,9$ будуть більш стабільними щодо мікроорганізмів. Оскільки в кислому середовищі мікроорганізми не лише погано розвиваються, але й погано переносять дію високих температур, швидко гинучи за нагрівання [23, с. 197].

Введення в рецептуру горіхів обумовило вміст жиру в купажованих пюре (табл. 3).

Цукрово-кислотний індекс у купажованих пюре, виготовлених за другим варіантом, був на оптимальному рівні, що відповідав гармонійному смаку. Але купажовані пюре, виготовлені за II варіантом, характеризувалися ЦКІ від 17,1 до 17,6. За органолептичною оцінкою однойменні овочеві пюре, взяті за контроль, отримали оцінку $4,05 \ldots 4,28$ бала. Купажовані пюре, виготовлені за II варіантом, $-4,35 \ldots 4,45$ бала. А от купажовані пюре, виготовлені за І варіантом вирізнялися збалансованістю та свіжістю й отримали оцінки $4,85 \ldots 4,90$ бала.
Вміст аскорбінової кислоти у купажованих пюре був вищим порівняно 3 контрольними варіантами (табл. 4). Як показали розрахунки, втрати АК в овочевих пюре, взятих за контроль, були в межах $17,2 \ldots 34,1 \%$, тоді як під час купажування й проварювання купажованих пюре - в межах $7,3 \ldots 14,0 \%$. Можна припустити, що зниження втрат обумовлено тим, що кисле середовище сприяло кращому збереженню АК.

Протилежний результат був отриманий стосовно $\beta$-каротину, вміст якого був вищим в однойменних овочевих пюре, взятих за контроль, порівняно $з$ купажованими. Це можна пояснити значно нижчим вмістом $\beta$-каротину в аличевому пюре, ніж у гарбузовому чи морквяному. Можна також зробити висновок, що $\beta$-каротин менше втрачався порівняно з АК під час купажування й проварювання (табл. 4). Крім того, очевидно, кисле середовище не сприяло його кращому збереженню. Втрати $\beta$-каротину в овочевих пюре, взятих за контроль, були 4,3...6,4\%, а у купажованих $-5,8 \ldots 7,8 \%$.

Всі варіанти виготовлених пюре за вмістом $\beta$-каротину $\epsilon$ функціональними продуктами й можуть бути використані як збагачувачі цим інгредієнтом для приготування різних харчових продуктів. За вмістом АК пюре, до рецептури яких входить гарбуз, можна вважати функціональними продуктами за цим інгредієнтом. Оскільки харчовий продукт може бути віднесений до функціональних харчових продуктів, якщо вміст біозасвоюваного функціо-

Таблиця 4

Вміст АК і $\beta$-каротину в готових пюре та втрати нутріснтів під час купажування й проварювання

\begin{tabular}{|c|c|c|c|c|}
\hline \multirow{2}{*}{ Назва пюре } & \multicolumn{2}{|c|}{ Вміст мг/100 г } & \multicolumn{2}{|c|}{ Втрати, \% } \\
\cline { 2 - 5 } & $\begin{array}{c}\text { аскорбінової кис- } \\
\text { лоти }\end{array}$ & $\boldsymbol{\beta}$-каротину & $\begin{array}{c}\text { аскорбінової кис- } \\
\text { лоти }\end{array}$ & $\boldsymbol{\beta}$-каротину \\
\hline Пюре 3 гарбуза (контроль) & 13,5 & 20,4 & 34,1 & 4,7 \\
\hline $\begin{array}{c}\text { Пюре гарбузово-аличеве 3 горіхами } \\
\text { (І варіант) }\end{array}$ & 15,3 & 14,1 & 14,0 & 7,8 \\
\hline $\begin{array}{c}\text { Пюре гарбуово-аличеве 3 горіхами } \\
\text { (ІІ варіант) }\end{array}$ & 16,0 & 15,3 & 11,3 & 6,0 \\
\hline Пюре з моркви (контроль) & 4,8 & 21,8 & 17,2 & 6,4 \\
\hline $\begin{array}{c}\text { Пюре морквяно-аличеве 3 горіхами } \\
\text { (І варіант) }\end{array}$ & 6,8 & 15,4 & 9,5 & 7,3 \\
\hline $\begin{array}{c}\text { Пюре морквяно-аличеве 3 горіхами } \\
\text { (І варіант) }\end{array}$ & 6,5 & 16,4 & 7,3 & 7,3 \\
\hline Пюре з моркви та гарбуза (контроль) & 10,2 & 21,4 & 22,4 & 4,3 \\
\hline $\begin{array}{c}\text { Пюре морквяно-гарбузово-аличеве } \\
\text { 3 горіхами (І варіант) }\end{array}$ & 11,6 & 14,9 & 8,3 & 6,6 \\
\hline $\begin{array}{c}\text { Пюре морквяно-гарбузово-аличеве } \\
\text { з горіхами (ІІ варіант) }\end{array}$ & 11,4 & 16,0 & 9,0 & 5,8 \\
\hline НІР & 0,3 & 0,06 & & \\
\hline
\end{tabular}


нального інгредіснта в ньому в межах від 10-50\% середньої добової потреби [24, с. 40].

За результатами наших досліджень можна рекомендувати приготування овочево-фруктових пюре за такими рецептурами (г на 1000 г продукту): пюре з гарбуза, моркви чи моркви та гарбуза в рівних частинах - 700 г; пюре 3 аличі 200 г; цукор білий і порошок з ядра волоського горіха - по 50 г.

Характеристика готових страв:

- зовнішній вигляд: однорідна протерта маса, без грудочок;

- колір: однорідний по всій масі, насичений оранжевий;
- консистенція: густа, однорідна, без грудочок і шматочків непротертих овочів і фруктів;

- запах і смак: смак приємний, властивий овочам після теплової обробки, з приємною кислинкою.

Висновки. В результаті досліджень установлено, що розроблені рецептури купажованих пюре забезпечують приготування продуктів з підвищеною біологічною цінністю, покращеними органолептичними й функціональними властивостями.

Результати проведеного дослідження можна запропонувати для використання в молочній, хлібопекарній, консервній промисловості та в закладах ресторанного господарства.

\section{Список літератури:}

1. Смоляр В.І. Формула раціонального харчування. Проблеми харчування. 2013. № 1. С. 5-9.

2. Батурин А.К., Мендельсон Г.И. Питание и здоровье: проблемы XXI века. Пищевая промышленность. 2005. № 5. C. 105-107.

3. Кудряшов А.А. Пища XXI века и особенности ее создания. Пищевая промышленность. 1999. № 12. C. $48-50$.

4. Капрельянц Л.В., Петросьянц А.П. Лікувально-профілактичні властивості харчових продуктів та основи дієтології. Одеса : Друк, 2011. С. 26-28, 34-35, 96.

5. Кравець Т. Комора вітамінів. Харчова і переробна промисловість. 1992. № 4. С. 7.

6. Смоляр В.И. Рациональное питание. Київ: Наукова думка, 1991. 368 с.

7. Стахмич Т.М., Пахолюк О.М. Кулінарне мистецтво : підручник у двох книгах. Кн. 1: Технологія приготування їжі. Київ : Грамота, 2008. С. 233-234, 247-248.

8. Клопотенко Є. Збірник рецептур страв для харчування дітей шкільного віку в організованих освітніх та оздоровчих закладах. Львів : Літопис, 2020. С. 38, 72, 98.

9. Тюрікова I.С., Пересічний М.І. Використання біологічно цінного волоського горіха / Науковий вісник Полтавського університету економіки і торгівлі. 2015. № 1 (73). С. 27-37.

10. Степанова В.С. Розробка технологій напоїв і соусної продукції на основі горіхоплідної та насіннєвої сировини : дис. ... канд. тех. наук : 05.18.16. Одеса, 2018. С. 105-106.

11. Іваніщева О.А. Дослідження шляхів оптимізації нутрієнтного складу страв з гарбуза. Молодий вчений. 2019. № 4 (68). С. 192-195.

12. Технологія харчових продуктів із заданими властивостями на основі вторинної молочної та рослинної сировини : монографія / В.А. Гніцевич та ін. Донецьк : ДонНУЕТ, 2014. С. 24-25.

13. Нові бісквіти та хлібобулочні вироби, вітамінізовані натуральними коротиноїдними рослинними нанодобавками для оздоровчого харчування / Павлюк Р.Ю. та ін. Збірник наукових пращь Харківського державного університету харчування та торгівлі. Секиія 1 «Нові технології продуктів харчування». Харків, ХДУХТ. 2016. С. 15-30.

14. Загорулько О.С., Загорулько А.М., Гордієнко I.О. Розробка способу виробництва напівфабрикатів 3 плодоовочевої сировини. Нові технології і обладнання харчових виробництв : матеріали Міжвузівського науково-практичного семінару, м. Полтава, 18 квітня 2019 р. Полтава : ПУЕТ, 2019. С. 7-8.

15. Бородай А.Б., Суткович Т.Ю. Дослідження впливу каротиновмісних збагачувачів на якість хліба. Нові технології і обладнання харчових виробництв : матеріали Міжвузівського науково-практичного семінару, м. Полтава, 18 квітня 2019 р. Полтава : ПУЕТ, 2019. С. 17-19.

16. ГОСТ 24556-89. Межгосударственный стандарт. Продукты переработки плодов и овощей. Метод определения витамина С. Москва : ИПК Издательство стандартов, 2003. 12 с.

17. ДСТУ 6045:2008. Метод визначання $\mathrm{pH}$. Фрукти, овочі та продукти переробляння, консерви м'ясні та м’ясо-рослинні. [Чинний від 2009-01-01]. Вид. офіц. Київ : Держспоживстандарт України, 2009. 12 с.

18. ДСТУ 4305:2004. Фрукти, овочі та продукти їх переробляння. Метод визначення каротину. Вид. офіц. Київ : Держспоживстандарт України, 2005. 18 с.

19. ДСТУ ISO 2173:2007 (ISO 2173: 2003, IDT). Визначення розчинних сухих речовин рефрактометричним методом. Продукти 3 фруктів та овочів. [Чинний від 2009-01-01]. Вид. офіц. Київ : Держспоживстандарт України, 2010. 7 с. 
20. ДСТУ 4954:2008. Методи визначення цукрів. Продукти перероблення фруктів та овочів. [Чинний від 2009-01-01]. Вид. офіц. Київ : Держспоживстандарт України, 2009. 17 с.

21. ДСТУ 4957:2008. Методи визначення титрованої кислотності. Продукти перероблення фруктів та овочів. [Чинний від 2009-07-01]. Вид. офіц. Київ : Держспоживстандарт України, 2009. 10 с.

22. Шабров А.В., Дадали В.А., Макаров В.Г. Биохимические основы действия микрокомпонентов пищи. Москва : Авалон, 2003. С. 34.

23. Фізико-хімічні і біологічні основи консервного виробництва / Б.Л. Флауменбаум та ін. Одеса : Друк, 2006. С. 197.

24. Шендеров Б.А. Функциональное питание и его роль в профилактике метаболического синдрома. Москва: ДеЛи принт, 2008. С. 40.

\section{Tokar A.Yu., Kharchenko Z.M., Matenchuk L.Yu., Voitsekhivskyi V.I. FUNCTIONAL FRUIT AND VEGETABLE PUREES UNDER MOBERN EQUIPMENT APPLICATION}

The article deals with the results of a study on the development of fruit and vegetable purees from pumpkin, carrots, cherry plums and walnuts. Such new types of purees as pumpkin-cherry plum puree with nuts, carrotcherry plum puree with nuts and pumpkin-cherry carrot-plum puree with nuts predominate over the single vegetable purees under their chemical composition. Two variants of formulas were studied, which differed in the amount of added cherry plum puree. Due to the organoleptic quality evaluation, preference is given to the formula consisting of $70 \%$ vegetable puree, $20 \%$ cherry plum puree, $5 \%$ nuts and sugar. In particular, multifruit purees made according to this formula contain $18.8 \ldots 19.4 \%$, of dry soluble substances, about $12 \%$ sugar, $0.7 \%$ of titrated acidity and have an active acidity of $3.7 \mathrm{pH}$ units, which provides higher microbiological stability. New types of puree also contain natural fats rich in unsaturated fatty acids and pectins. Multifruit purees have a pleasant slightly sour taste due to natural organic acids and received an organoleptic quality evaluation of 4.85 ...4.90 points. The content of ascorbic acid in pumpkin-cherry plum puree with nuts is $15.3 \mathrm{mg}$ per $100 \mathrm{~g}$, $\beta$-carotene - $14.1 \mathrm{mg}$ per $100 \mathrm{~g}$; in carrot-cherry plum puree with nuts and in pumpkin-carrot-cherry plum puree with nuts - 6.8, 15.4 and 11.6, 14.9 respectively. Such purees are functional products according to the $\beta$-carotene content and can be used as the enriching agents of this ingredient for the preparation of various foods. According to the ascorbic acid content such purees, which formula includes pumpkin, can be considered functional products under this ingredient. The developed recipes for multi-fruit purees provide the preparation of foodstuffs with high biological value, improved organoleptic and functional properties. The results of this study can be offered for use in the dairy industry, baking industry, food canning industry industry and restaurants.

Key words: pumpkin, carrot, cherry plum, walnuts, multi-fruit puree, ascorbic acid, $\beta$-carotene, functional products, enriching agents. 